\title{
GLP1 and cancer: friend or foe?
}

\author{
Roman Vangoitsenhoven ${ }^{1,2}$, Chantal Mathieu ${ }^{1,3}$ and \\ Bart Van der Schueren ${ }^{1,3}$
}

${ }^{1}$ Laboratory of Experimental Medicine and Endocrinology, Catholic University of Leuven, Leuven, Belgium

Departments of ${ }^{2}$ Internal Medicine and ${ }^{3}$ Endocrinology, University Hospitals Leuven, Leuven, Belgium

(Correspondence should be addressed to B Van der Schueren at Department of Endocrinology, University Hospitals Leuven, Herestraat 49, 3000 Leuven, Belgium; Email: bart.vanderschueren@uzleuven.be)

\begin{abstract}
The new incretin-based therapies, dipeptidyl peptidase-4 (DPP4) inhibitors and glucagon like peptide 1 (GLP1) receptor agonists are widely used for the treatment of type 2 diabetes because of their glucose-lowering capacity with low risk of hypoglycemia. As they are weight neutral or induce weight loss in this mostly overweight population, they are popular among clinicians and patients alike. Nonetheless, concerns have been raised about GLP1's trophic effects. While increased $\beta$ cell mass observed in rodents sounds appealing for treatment of diabetes, there was also an increased incidence of medullary thyroid cancer (MTC) in some species. We reviewed literature available in the Medline database until March 2012. Safety signals have emerged for MTC and pancreatic carcinoma from adverse event databases in the United States and Europe. Considering the relatively short duration of these studies, it is more likely that premalignant lesions are stimulated in presence of GLP1, rather than new neoplasms induced. Moreover, interpreting results of animal studies is difficult because of species-specific differences in presence and density of GLP1 receptors. Furthermore, data are emerging suggesting beneficial effects of GLP1 on colon and breast cancer. In conclusion, presently, the benefits of using DPP4 inhibitors or GLP1 receptor agonists for treatment of type 2 diabetes outweigh the risks. Nonetheless, their safety profile should be monitored and their indications should be widened cautiously. At present they remain contra-indicated in patients with a personal or family history of MTC or multiple endocrine neoplasia type 2.
\end{abstract}

Endocrine-Related Cancer (2012) 19 F77-F88

\section{Introduction}

Type 2 diabetes mellitus is a relentless chronic disease, characterized by insulin resistance and deficient insulin secretion leading to hyperglycemia, which is the hallmark of the condition. Driven by the obesity epidemic, there has been a continuous rise in the prevalence of type 2 diabetes throughout the world. With the current estimate of more than 350 million patients worldwide (IDF Diabetes atlas, http://www. idf.org/diabetesatlas/5e/diabetes, accessed 23 March 2012), it is considered to be one of the major health challenges of the 21 st century. Diabetes associated comorbidities are putting an important strain on the already stretched health care budgets of western and developing countries and despite a broad therapeutic arsenal to treat hyperglycemia, diabetes remains the most frequent cause of blindness, amputations, and dialysis worldwide (IDF Diabetes atlas). It is obvious that the scientific world is keen to provide new therapeutic strategies, and recently a new class of drugs has reached the market. They are all based on the so-called incretin effect, known since the early 1900s (Bayliss \& Starling 1902, Moore 1906; see below).

This class of drugs works by either increasing the concentration of the endogenous incretins by preventing deactivation by dipeptidyl peptidase-4 (DPP4) inhibitors (Ahren et al. 2002) or by mimicking the incretins biochemically (glucagon like peptide 1 (GLP1) receptor agonists) while being protected from DPP4 deactivation (Fineman et al. 2003). Of the latter, homologues (exenatide) and analogues (liraglutide) are clinically available at this time.

Both DPP4 inhibitors and GLP1 receptor agonists are appealing therapies because of their 
glucose-lowering capacity with low risk of inducing hypoglycemia. In addition, they have an excellent metabolic safety profile and are weight neutral or induce weight loss.

However, as with any new class of drugs, caution is warranted. In particular, because these drugs will be used by patients for many years due to the chronicity of type 2 diabetes. But there is more. GLP1 receptor activation directly promotes cell proliferation and enhances cell survival in several tissues including $\beta$-cells, neurons, fibroblasts, and cardiomyocytes (Brubaker \& Drucker 2004). Therefore, there is a theoretical possibility of inducing neoplasms.

In this article, we address the potential link between the incretins, in particular GLP1, and neoplasms and discuss the available evidence.

\section{The incretin effect and its therapeutic application}

The concept that oral nutrient (glucose) intake promotes a much greater degree of insulin secretion compared with a parenteral isoglycemic glucose infusion dates from the beginning of last century and is called the incretin effect (Bayliss \& Starling 1902, Moore 1906). It was in the 1980s that the gastrointestinal hormones involved were identified and called incretins (Ghiglione et al. 1984, Nauck et al. 1989). GLP1 and gastric inhibitory peptide (GIP) are the most important incretins. They enhance the postprandial insulin secretion and inhibit glucagon secretion, thus maintaining glucose homeostasis following a meal (Kreymann et al. 1987). GLP1 and GIP also delay gastric emptying (Imeryuz et al. 1997) and reduce food intake (Baggio \& Drucker 2004), which explains the positive effect of incretin mimetics and DPP4 inhibitors on weight. The incretins have also been shown to have a trophic effect on $\beta$ cell mass (Xu et al. 1999). In addition, a wide range of cardiovascular benefits have been claimed, such as lowering of blood pressure and postprandial lipids (Ban et al. 2009). Finally, reduction in markers of inflammation and oxidative stress has been reported (Kodera et al. 2011).

In physiological circumstances, GLP1 and GIP have an extremely short half-life as they are almost immediately inactivated by the enzyme DPP4 (Kieffer et al. 1995). Pharmaceutical industry has circumvented this issue by developing small molecules that are inhibitors of this enzyme (DPP4 inhibitors, orally active), thus increasing the levels of the subject's own incretins. Levels are still following the physiological profile, with lower levels when fasting and peaks after meals. Moreover, the highest levels are detected in the portal circulation (Hjollund et al. 2011). The second path industry has taken till now, is the introduction of GLP1 homologues (exenatide and lixisenatide) or analogues (liraglutide, dulaglutide, and albiglutide). These molecules are peptides (which precludes oral administration) that are partially resistant to the degradation by DPP4 enzymes, and further prolong their presence in blood by slower renal elimination. These products are administered once or twice daily, but through galenic innovations also more protracted release forms have been made (once weekly or once monthly exenatide). After injection of these products, GLP1 levels are increased to much higher levels than those observed with DPP4 inhibitors and the levels stay high, even in fasting circumstances. Moreover, these high levels are also present in the peripheral circulation (Agerso et al. 2002).

The elevation of circulating incretin concentrations is a desired effect in patients with type 2 diabetes as it restores the incretin effect that has been shown to be blunted in type 2 diabetes (Vilsboll et al. 2001). Nonetheless, incretins are present throughout the human body and are believed to play a role in numerous physiological processes. Therefore, interfering with their levels might have off-target effects. In order to limit the extent of this review, we chose to discuss potential effect of GLP1 level altering therapies, as this is the most relevant in today's clinical setting.

\section{GLP1: an ubiquitous hormone/neuropeptide}

GLP1 is released postprandially from the L-cells in the intestine, mainly in the distal ileum and colon (Sjolund et al. 1983).

The main effects of GLP1 are mediated by GLP1 receptors in the pancreas, intestine, stomach, and the sensory and central nervous systems, heart, pituitary, lung, and kidney (Bullock et al. 1996).

GLP1 binds to its specific G-protein coupled receptor, which activates downstream pathways including cAMP/protein kinase A (PKA), cAMP/guanine-nucleotide exchange factor (Epac) or phosphatidylinositol-3 kinase/PKC pathways (Gromada et al. 1998, Kang et al. 2003, MacDonald et al. 2003; see Fig. 1).

In the $\beta$ cell, GLP1 receptor activation accelerates glycolytic and mitochondrial metabolism of glucose while also rendering K-ATP channels more sensitive to the increase of ATP/ADP concentration ratio generated by the intracellular metabolism of glucose. The closure of the ATP-sensitive $\mathrm{K}^{+}$channels leads to depolarization of the $\beta$ cell and the subsequent influx of 


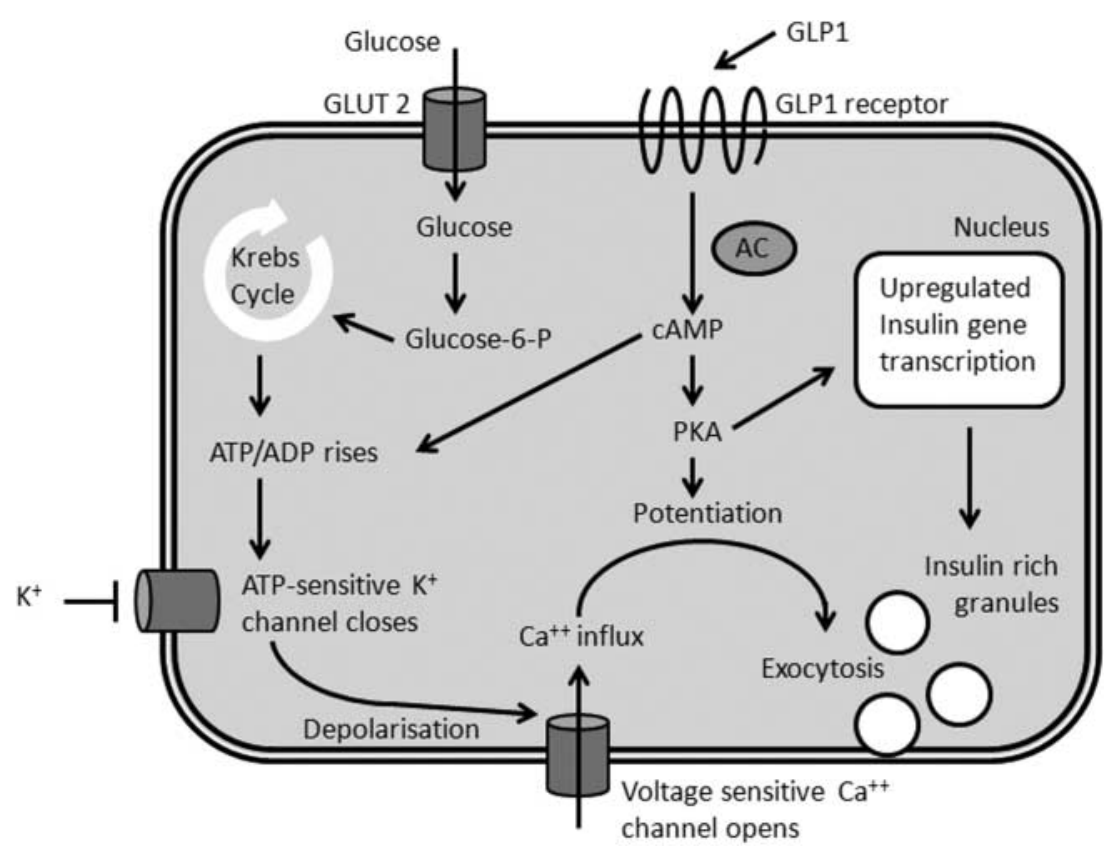

Figure 1 Mechanism of glucose-dependent, GLP1-potentiated insulin secretion in the $\beta$ cell. AC, adenylate cyclase; GLUT2, glucose transporter 2, PKA, protein kinase A.

calcium results in exocytosis of insulin. In other words, GLP1 augments glucose-induced membrane depolarization and therefore enhances insulin secretion in a glucose-dependent manner.

In the $\alpha$-cell, GLP1 receptor activation inhibits glucagon secretion. In combination with enhanced insulin secretion this decrease of glucagon leads to an improvement of glucose homeostasis, in particular in patients with type 2 diabetes. As stated above, DPP4 inhibitors and GLP1 receptor agonists are weight neutral or even lead to weight loss, which sets them apart from almost all other available drugs for the treatment of diabetes, with the exception of the biguanides and acarbose. All of the above characteristics explain the commercial success of this relatively new class of drugs.

But GLP1 seems to have much wider effects on the function and survival of cells that express its receptor. In vitro, insulin-gene transcription is stimulated while cell apoptosis is inhibited by GLP1 receptor activation (Drucker et al. 1986, Fehmann \& Habener 1992) and even stimulates cell growth (Stoffers et al. 2000), which raise the issue of whether activation of the GLP1 receptor pathway might have positive (i.e. restoration of the functional $\beta$ cell mass) or negative (i.e. inducing proliferation of premalignant lesions) effects when chronically used for the treatment of type 2 diabetes.

\section{GLP1: a foe}

The main tissues where concerns around the trophic effects of GLP1 and its potential carcinogenic properties have been raised in the clinical development plans of both the GLP1 receptor agonists and DPP4 inhibitors are pancreas and thyroid.

\section{Pancreas}

There have been reports suggesting that both treatment with exenatide (also known as Exendin-4; Denker \& Dimarco 2006, Cure et al. 2008, Tripathy et al. 2008) and liraglutide (Buse et al. 2009), the most commonly used GLP1 receptor agonists, is associated with an increased risk of pancreatitis. As chronic pancreatitis is also a known risk factor for pancreatic cancer through cytotoxicity of inflammatory cytokines, reactive oxygen species and proliferation (Jura et al. 2005, Rebours et al. 2009), there might thus be an increased risk of pancreatic cancer, a condition with an often fatal prognosis.

Evaluation of the U.S. Food and Drug Administration (FDA) adverse event database (AERS) in 2011 by Elashoff et al. (2011) showed a six- to 10-fold increase in pancreatitis in patients treated with the DPP4 inhibitor sitagliptin (131 events) and GLP1 receptor agonist exenatide (971 events) respectively in comparison with patients treated with the control drugs rosiglitazone, nateglinide, reparglinide, and glipizide 
(43 events). The reported event rate for pancreatic cancer was 2.9 times higher for exenatide ( 81 events) and 2.7 times greater for sitagliptin (16 events), compared with control therapies (13 events). The absolute numbers of these events are of course very small, compared with the vast number of patients included in the database between 2004 and 2009.

In the German adverse event database, reporting of pancreatic cancer was also unusually high in association with exenatide (11 cases in 4 years, with yearly 15 000-25000 treated patients), but there was no significant increase for the DPP4 inhibitors (Arzneimittelkommission der deutschen Ärzteschaft 2011). The mean treatment duration with exenatide in the German patients who developed pancreas carcinoma was only 12 months (range 2-33 months). This seems too short to induce new tumor development, given the observed 10-year interval between tumor induction, growth, and clinical diagnosis (Yachida et al. 2010). However, it is possible that chronic pancreatitis and premalignant PanIN lesions could be subject to GLP1 stimulation, and progression to malignancy.

Koehler \& Drucker have studied the effect of GLP1 activation on the growth and survival of human pancreatic adenocarcinoma cells in short-term studies in vitro and longer term experiments in mice in vivo. They proved that the human pancreatic cancer cell lines of both the pancreatic ductal adenocarcinoma (CAPAN-1, CFPAC-1, and PL45) and the carcinoma (Hs 7766T) cell lines express the GLP1 receptor. However, there are differences in GLP1 receptor dependent activation of ERK1/2 and cAMP, indicating that there may be a difference in relative level of GLP1 receptor expression on the surface of the different cell types studied (Koehler \& Drucker 2006). As the ERK1/2 and to a lesser extent cAMP pathways are known to be involved in functions including the regulation of meiosis and mitosis and as they are also activated by carcinogens, the question raised is whether GLP1 receptor agonist might have pro-oncogenic characteristics. But findings have been inconsistent.

Korner et al. (2007) were unable to detect GLP1 receptors in 21 human pancreatic adenocarcinomas with the use of receptor autoradiography. Therefore GLP1 receptor expression in these tumors may be restricted to cell lines and may not be relevant in humans in vivo. In experiments conducted by Koehler \& Drucker (2006), exenatide did not modulate the growth rate of pancreatic cancer cell lines expressing the GLP1 receptor, nor did it rescue GLP1 receptorexpressing pancreatic cancer cells from drug-induced cell death. In addition, sustained GLP1 receptor activation by exenatide did not promote the progression of pancreatic tumor development or growth in mice.

As noted above, the increased incidence of pancreatic cancer might be indirect through the observed increase in pancreatitis. Putative mechanisms to explain this increased incidence of pancreatitis is that incretins might facilitate gallstone formation because they prolong gastric emptying and thus increase the contractility of the sphincter of Oddi, which hinders the drainage of bile acids and pancreatic enzymes. In addition, GLP1 receptor agonist induces weight loss that is known to promote the formation of gallstones, though the weight loss achieved seems rather insufficient to really have an impact on lithiasis (Imeryuz et al. 1997).

From in vitro data, other mechanisms to explain a link between incretin-based therapy and pancreatitis have emerged. Sitagliptin, a DPP4 inhibitor, was found to increase ductal proliferation of the exocrine pancreas in rats, with ductal metaplasia in some animals and one case of pancreatitis (Matveyenko et al. 2009). Exenatide, the most studied GLP1 receptor agonist, has also been shown to promote pancreatic duct hyperplasia in rats (Nachnani et al. 2010). Ductal proliferation and metaplasia are wellestablished features of human pancreatitis and risk factors for pancreatic cancer (Jura et al. 2005, Rebours et al. 2009).

Animal data have been relatively reassuring up until now, although they do not allow to completely eliminate doubt. Nyborg et al. (2012) conducted a study to investigate whether long-term treatment with liraglutide, a once-daily GLP1 analogue, induces pancreatitis or preneoplastic lesions in pancreata of mice, rats, and nonhuman primates. They found that three out of 79 mice in the male control group and five out of 280 male mice in different dose treatment groups developed pancreatitis. In the female control group none of the 79 examined mice had microscopic signs of pancreatitis, but 12 out of 275 of the treated animals did. None of the 399 rats developed pancreatitis, nor any treatment-related effects concerning islet cell hyperplasia or benign adenomas after 2 years of treatment with liraglutide. There were no histological signs of pancreatitis in nonhuman primates after 52 weeks of treatment. However, after 87 weeks focal inflammatory cell infiltration in the pancreas was seen in three out of five animals of the high dose group. There were no signs of proliferative or preneoplastic lesions in nonhuman primates, even after 87 weeks of treatment. In the mice treated for 104 weeks with high dose liraglutide, equivalent to 36 -fold higher than the maximal recommended dose in humans, more findings 
of diffuse edema, inflammatory cell infiltration and vacuolation were seen, but the numbers were not statistically significant. The conclusion of the authors is that although these data are derived from nondiabetic animals, simple pharmacological induction of pancreatitis by GLP1 receptor agonists seems unlikely (Nyborg et al. 2012).

In this context, it is important to keep in mind that all patients with type 2 diabetes and/or obesity have greater risk on pancreatitis than nondiabetic patients (Girman et al. 2010), possibly through increased frequency of pancreatic duct replication (Jura et al. 2005, Butler et al. 2010). Therefore, assessing the contribution of GLP1 receptor activation on the development of pancreatitis in diabetic patients might be compromised. Moreover, there have been reports stating that the incidence of pancreatitis for exenatide in GLP1 receptor agonist-treated patients did not differ from that of a background population suffering from type 2 diabetes (Garg et al. 2010, Dore et al. 2011). The question on a putative link between the increased incidence of pancreatitis and pancreatic adenocarcinoma and the use of GLP1 receptor agonists thus remains unanswered. Moreover, increased awareness for detecting (biochemical) pancreatitis and, as for all new drugs, important reporting bias might be present.

\section{Thyroid}

It has been observed in preclinical studies that the incidence of thyroid C-cell tumors was increased in rodents treated with GLP1 analogues (http://www.fda. gov/downloads/Advisory-Committees/Committees\% 20MeetingMaterials/Drugs/EndocrinologicandMetabolicDrugs AdvisoryCommittee/UCM151129.pdf; accessed 12 April 2012, Bjerre Knudsen et al. 2010). Therefore, monitoring for thyroid cancer has been a focus in the clinical development plan of all DPP4 inhibitors and GLP1 receptor agonists, but this far the data have been reassuring.

There are several factors that could explain the discrepancy between preclinical and clinical data.

First of all, GLP1 receptor expression on thyroid C-cells is known to be species specific and observation in rodents might thus not have relevance in humans. In mouse and rat thyroid gland C-cells, GLP1 receptor densities were 22- and 45-fold higher than that reported for humans and cynomolgus monkeys respectively (Bjerre Knudsen et al. 2010, Waser et al. 2011). However, the contention that normal human thyroid tissue does not express the GLP1 receptor has been challenged recently. Gier et al. (2012) demonstrated that GLP1 receptors were expressed in thyroid tissue of controls (5/15 cases) and in thyroids of patients with C-cell hyperplasia (9/9 cases), papillary carcinoma (3/15 cases), and medullary carcinoma (11/12). Available data on the presence GLP1 receptor in different species and tissues are given in Table 1.

It comes as no surprise that in view of the difference in receptor density, the cell response to GLP1 receptor activation is also species specific. Monkey's thyroid C-cells do not exhibit a proliferative response to the GLP1 agonist liraglutide not even at an exposure up to 60 -fold that of the maximum recommended human dose (Bjerre Knudsen et al. 2010). In contrast, in rats and mice long-term liraglutide administration up to 104 weeks, causes C-cell hyperplasia and C-cell tumor formationin in a dose-dependent manner (Bjerre Knudsen et al. 2010). With exenatide, a higher incidence of C-cell lesions was observed in female rats, but none of the animals developed a carcinoma (Bjerre Knudsen et al. 2010). The relevance of the latter observation remains a matter of debate (Table 2).

Data gained from several prospective clinical studies, showed no increased calcitonin levels under therapy with GLP1 receptor agonists in patients with diabetes mellitus type 2 (Bjerre Knudsen et al. 2010, Hegedus et al. 2011). In contrast, in mice and rats, liraglutide, as well as native GLP1, exenatide, taspoglutide, and lixisenatide, potently activated the GLP1 receptor in rat thyroid C-cells and stimulate

Table 1 Difference between species in regard to the presence of glucagon like peptide 1 receptors

\begin{tabular}{lccc}
\hline & $\begin{array}{c}\text { Gier } \\
\text { et al. }\end{array}$ & $\begin{array}{c}\text { Waser } \\
\text { et al. }\end{array}$ & Körner et al. \\
\hline Human & & & \\
Normal thyroid & $5 / 15(33 \%)$ & $0 / 6(0 \%)$ & $1 / 18(6 \%)$ \\
$\begin{array}{l}\text { C-cell hyperplasia } \\
\text { Papillary thyroid }\end{array}$ & $\begin{array}{c}\text { 3/9 (100\%) } \\
\text { carcinoma }\end{array}$ & & \\
Medullary thyroid & $11 / 12(92 \%)$ & $10 / 36(28 \%)$ & $5 / 18(28 \%)$ \\
carcinoma & & & \\
Rat & & $4 / 6(67 \%)$ & $12 / 12(100 \%)$ \\
Normal thyroid & & $11 / 11(100 \%)$ & \\
C-cell hyperplasia & & & \\
Papillary thyroid & & $5 / 5(100 \%)$ & \\
carcinoma & & & \\
Medullary thyroid & & & \\
carcinoma & & & \\
Mice & & & \\
Normal thyroid & & & \\
C-cell hyperplasia & & & \\
Papillary thyroid & & & \\
carcinoma & & & \\
Medullary thyroid & & & \\
carcinoma & & & \\
\hline
\end{tabular}


$R$ Vangoitsenhoven et al.: GLP1 and cancer: friend or foe?

Table 2 Overview of available data on possible oncogenic effects of glucagon like peptide 1 (GLP1) in different tissues and species

\begin{tabular}{|c|c|c|c|c|c|}
\hline Tissue & Cell & Agent & Species & Effect & References \\
\hline \multirow[t]{8}{*}{ Pancreas } & $\begin{array}{l}\text { Cell lines (CAPAN-1, } \\
\text { CFPAC-1, PL45, } \\
\text { PANC-1, Hs 766T) }\end{array}$ & Exenatide & In vitro & $\begin{array}{l}\text { Activates ERK1/2 in a } \\
\text { GLP1R-dependent manner }\end{array}$ & $\begin{array}{l}\text { Koehler \& Drucker } \\
\quad(2006)\end{array}$ \\
\hline & & Exenatide & In vitro & $\begin{array}{l}\text { Does not modulate growth rate of } \\
\text { pancreatic cancer cell lines } \\
\text { expressing GLP1R }\end{array}$ & $\begin{array}{l}\text { Koehler \& Drucker } \\
\quad(2006)\end{array}$ \\
\hline & & Exenatide & In vitro & $\begin{array}{l}\text { Does not rescue GLP1-expressing } \\
\text { cancer cells from drug-induced cell death }\end{array}$ & $\begin{array}{l}\text { Koehler \& Drucker } \\
\quad(2006)\end{array}$ \\
\hline & & Exenatide & Mouse & $\begin{array}{l}\text { Does not modulate the propagation of } \\
\text { GLP1R-expressing pancreatic cancer cell } \\
\text { lines in vivo }\end{array}$ & $\begin{array}{l}\text { Koehler \& Drucker } \\
\quad(2006)\end{array}$ \\
\hline & Islet cells & Liraglutide & Mouse & $\begin{array}{l}\text { No overt macroscopic signs of } \\
\text { panceatitis after } 2 \text { years' exposure }\end{array}$ & Nyborg et al. (2012) \\
\hline & & Liraglutide & Mouse & $\begin{array}{l}\text { No significant difference in islet } \\
\text { hyperplasia or islet cell carcinoma } \\
\text { compared with control }\end{array}$ & Nyborg et al. (2012) \\
\hline & & Liraglutide & Rat & $\begin{array}{l}\text { No difference in pancreatitis compared } \\
\text { with control }\end{array}$ & Nyborg et al. (2012) \\
\hline & & Liraglutide & Monkey & $\begin{array}{l}\text { No significant difference in pancreatitis or } \\
\text { preneoplastic lesions in monkeys }\end{array}$ & Nyborg et al. (2012) \\
\hline \multirow[t]{7}{*}{ Thyroid } & C-cell & Liraglutide & Rat & $\begin{array}{l}\text { Stimulates calcitonin release in a } \\
\text { dose-dependent manner and } \\
\text { calcitonin gene expression }\end{array}$ & $\begin{array}{l}\text { Bjerre Knudsen et al. } \\
\quad(2010)\end{array}$ \\
\hline & & Liraglutide & Rat & $\begin{array}{l}\text { Long-term GLP1R stimulation of } 104 \text { weeks } \\
\text { causes C-cell hyperplasia and tumor } \\
\text { formation }\end{array}$ & $\begin{array}{l}\text { Bjerre Knudsen et al. } \\
\quad(2010)\end{array}$ \\
\hline & & Liraglutide & Mouse & $\begin{array}{l}\text { Induces C-cell hyperplasia, but no } \\
\text { RET activation }\end{array}$ & $\begin{array}{l}\text { Bjerre Knudsen et al. } \\
\text { (2010) }\end{array}$ \\
\hline & & Exenatide & Mouse & Induces C-cell hyperplasia & $\begin{array}{l}\text { Bjerre Knudsen et al. } \\
\text { (2010) }\end{array}$ \\
\hline & & Liraglutide & Monkey & $\begin{array}{l}\text { C-cells do not exhibit a proliferative response } \\
\text { to GLP1R activation }\end{array}$ & $\begin{array}{l}\text { Bjerre Knudsen et al. } \\
\text { (2010) }\end{array}$ \\
\hline & & Liraglutide & Human & $\begin{array}{l}\text { Calcitonin levels do not rise in human subjects } \\
\text { with type } 2 \text { diabetes mellitus }\end{array}$ & $\begin{array}{l}\text { Bjerre Knudsen et al. } \\
\text { (2010) }\end{array}$ \\
\hline & & Exenatide & Rat & $\begin{array}{l}\text { Is associated with a high incidence of C-cell } \\
\text { lesions in female rats, but no carcinoma }\end{array}$ & $\begin{array}{l}\text { Bjerre Knudsen et al. } \\
\text { (2010) }\end{array}$ \\
\hline \multirow[t]{5}{*}{ Colon } & CT26 (cell line) & Exenatide & In vitro & $\begin{array}{l}\text { Inhibits GSK3 and ERK1/2 in } \\
\text { GLP1R-dependent manner }\end{array}$ & Koehler et al. (2011) \\
\hline & & Exenatide & In vitro & $\begin{array}{l}\text { Inhibits proliferation and induces } \\
\text { apoptosis }\end{array}$ & Koehler et al. (2011) \\
\hline & & Exenatide & In vitro & Inhibits colony formation in soft agar & Koehler et al. (2011) \\
\hline & & Exenatide & In vitro & Enhances irinotecan-induces apoptosis & Koehler et al. (2011) \\
\hline & & Exenatide & Mouse & $\begin{array}{l}\text { Does not modulate propagation of CT26 cells } \\
\text { in vivo, but induces higher apoptosis rate }\end{array}$ & Koehler et al. (2011) \\
\hline \multirow[t]{4}{*}{ Breast } & MCF-7 (ER+) & Exenatide & In vitro & Inhibits growth of breast cancer cells & Ligumsky et al. (2012) \\
\hline & $\begin{array}{l}\text { MDA-MB-231 } \\
\quad(\text { ER }-; \text { cell lines })\end{array}$ & Exenatide & In vitro & Induces p38 activation & Ligumsky et al. (2012) \\
\hline & & Exenatide & In vitro & Sensitizes MCF-7 cells to chemotherapy & Ligumsky et al. (2012) \\
\hline & & Exenatide & Mouse & Inhibits growth of breast cancer cells in vivo & Ligumsky et al. (2012) \\
\hline
\end{tabular}

calcitonin release in a dose-dependent manner, followed by increased calcitonin gene expression (Bjerre Knudsen et al. 2010). So once again, the preclinical observations cannot simply be translated to the clinic. Consequently, the FDA neither recommends monitoring of calcitonin levels (Parks \& Rosebraugh 2010), nor it recommends performing ultrasound imaging as screening tool in patients with incretinbased therapies.

Nonetheless, the preclinical finding that the incidence of an extremely rare cancer is increased should raise our guards. In the AERS database incidence rate of thyroid cancer in patients treated with exenatide was clearly higher - with an odds ratio 4.7 (30 events), 
compared with sitagliptin (two events) and the panel of control drugs (three events) (Elashoff et al. 2011). However, a second reason complicating the interpretation of the link between animal and clinical data, is the fact that the AERS does not differentiate between different types of thyroid cancer. A rise in total number of thyroid cancer may be attributed to promoting GLP1 receptor positive papillary carcinoma, more than through the extremely rare medullary thyroid carcinoma (Gier et al. 2012). In view of the relatively short time of the studies, as with pancreatic cancer, it seems more likely that small premalignant lesions are stimulated to grow, rather than new lesions are induced. Consequently, it seems dangerous to treat patients with a possible proliferative agent if they are suspected or known to have such a premalignant lesions. In patients with a known activating RET mutation C-cell hyperplasia is considered to be carcinoma in situ, and thus these patients should be regarded as a high-risk group. The relevance for sporadic C-cell hyperplasia still remains unclear (Livolsi \& Feind 1979). Recently, the group of Madsen et al. (2012) reported that liraglutide binding to the GLP1 receptor on C cells leading tot C-cell hyperplasia in wild type mice does not lead to RET kinase activation, but rather mTOR activation, which is reassuring to a certain extent as activation of this RET pathway is known to be pro-oncogenic.

A third convoluting factor is that rats develop spontaneous $\mathrm{C}$-cell lesions at a high frequency while in humans C-cell neoplasia is extremely rare (Roman et al. 2006).

The FDA obligation to monitor the annual incidence of medullary thyroid cancer (MTC) the first 15 years after approval of some of the GLP1 receptor agonists, might bring more clarity in the relevance of the preclinical safety signals in treated patients.

In conclusion, even though MTC is extremely rare, and the doses of liraglutide given to the rodents in the preclinical studies were higher than the maximal doses used in human patients (Bjerre Knudsen et al. 2010), the only practical guideline so far is that incretin-based therapy is contraindicated in patients with a personal or family history of medullary thyroid carcinoma or multiple endocrine neoplasia type 2 .

\section{GLP1: a loving friend?}

Much in contrast with the description in last paragraph, GLP1 receptor activation is believed to inhibit tumor growth in two common cancers: colon and breast.

\section{Colon}

The prevalence of colon cancer is higher in patients with type 2 diabetes, which is possibly related to a prolonged state of hyperinsulinemia. It has been hypothesized that insulin might promote cancer growth through activation of the insulin receptor (Tran et al. 1996). As GLP1 receptor activation enhances insulin secretion from the $\beta$ cell it might thus be expected that the increased insulin concentration might have a tumor-promoting effects. In this respect, one should also take into account that colon cancer cells express the GLP1 receptor, though this differs between cell lines.

Koehler et al. showed that the CT26 murine colon cancer cell line expresses an endogenous functional GLP1 receptor, but the adenocarcinoma cell lines DLD-1, SW480, CaCo2, HT29, and the normal colon cell line 18Co do not express the GLP1 receptor. Subsequently, they assessed the effect of GLP1 receptor agonists on cell differentiation and death. In vitro, exposure to exenatide induces morphological changes in CT26 cells. Exenatide inhibits proliferation and induces apoptosis of the cells. It also reduces colony formation in soft agar and even enhances irinotecan-induced apoptosis.

In vivo, these effects were confirmed as exenatide induced apoptosis of CT26 cells implanted into flanks of mice, but this did not affect tumor weight (Koehler et al. 2011).

To complicate things further, one should mention the potential carcinogenic potential of GLP2, which is known to be an important regulator of small and large intestine growth through cell proliferation (Drucker et al. 1996). GLP2 is structurally related to GLP1, but acts through a different receptor, for which GLP1 in turn has very little affinity (Munroe et al. 1999). Data on whether GLP2 modifies the growth or survival of murine or human intestinal tumor cells remain contradictory (Thulesen et al. 2004, Koehler et al. 2008). Continuous infusion of GLP1 did produce hyperplasia in the small intestine in rats, albeit significantly less than when GLP2 was infused (Ghatei et al. 2001).

As DPP4 inhibitors inhibit cleavage of both GLP1 and GLP2, they might thus create an extra intestinotrophic signal (Hartmann et al. 2000), which might increase the risk of promoting an already existing intestinal tumors (Masur et al. 2006).

So some elements seem to suggest that incretin treatment might promote tumor growth, while other point toward a role in tumor control and apoptosis. So far clinical data have not been able to establish whether increased concentrations of incretins should be 
considered as a friend or a foe in the context of intestinal tumors, but both are theoretically possible. Therefore further data should be gathered to further assess the carcinogenic, cancer promoting, or tumortoxic potential of the incretin-based therapies.

\section{Breast}

At this time, only Ligumsky et al. (2012) have published specific data on the relation between GLP1 receptor agonists and breast cancer.

In vitro, they noted that exposure to exenatide significantly reduces the number of colonies formed by MCF-7 (estrogen-receptor-positive) and MDAMB-231 (estrogen-receptor-negative) cells, whereas noncancerous HB2 cell were not affected. When MDA-MB-468 cells were injected to the flanks of nude mice, a dose-dependent reduction of tumor weight was observed in the mice treated with intraperitoneal exenatide. Exenatide induces p38 activation, which is usually related to growth inhibition or apoptosis and might thus explain the effects above observed (Xia et al. 1995).

Furthermore, doxorubicine and paclitaxel toxicity toward MCF-7 cells was enhanced in the presence of exenatide, indicating a chemotherapy sensitizing effect.

Of note is that exenatide induces an increase of cAMP and that its growth inhibitory effect is absent when adenylate cyclase is inhibited. The rise in cAMP is even more surprising given that the classic GLP1 receptor could neither be detected in breast cancer cells, nor in nontumorigenic mammary cells. The observed actions might be mediated through an alternative receptor that has not been identified yet. More daunting is that infection of MCF-7 cells with the pancreatic GLP1 receptor increases their proliferation and enhances activation of growth-promoting signaling pathways. Thus, once again, it remains unclear what the exact effect of prolonged exposure to elevated incretin levels will be in normal and tumorous breast tissue alike.

\section{Other tissues}

As GLP1 receptors are expressed in a wide range of tissues, including stomach, nervous system, pituitary, heart, lung, and kidney (Bullock et al. 1996), concerns about the possible proliferative effects of GLP1 receptor activation persist.

With the use of receptor autoradiography, the GLP1 receptor was located in various endocrine tumors, with particularly high amounts in pheochromocytomas, paragangliomas, and MTC, as well as in brain tumors (meningioma, astrocytoma, and ependymoma) and embryonic tumors. Most proliferative tissues, including pancreas adenocarcinoma, colorectal adenocarcinoma, breast carcinoma, and lymphomas, do not show expression of the GLP1 receptor, in imaging studies. A few of the tested ovarian and prostate carcinoma cases seemed GLP1 receptor positive (Korner et al. 2007). To our knowledge, no data exist on incidence of these malignancies during or after treatment with incretin-based therapies.

\section{Caveats}

When reviewing the limited data that are available so far, there are several impediments.

First, obesity and diabetes increase the incidence of a wide range of cancers, including tumors of the breast, pancreas, and colon (Giovannucci et al. 2010). So caution is warranted when interpreting the epidemiological data available for treatment with incretin-based therapies that are specifically used in this already highrisk population.

Second, the use of other antidiabetic drugs is a potential confounder when assessing the effect of incretin-based treatment strategies. As patients may take a mixture of several drugs and drug doses as well as regimens are frequently changed or combined, the analysis and searching for the culprit is difficult. Metformin, for example, which is frequently combined with incretin mimetics, is associated with a decreased cancer risk (Evans et al. 2005), and decreased mortality in cancer patients (Gallagher \& LeRoith 2011). Sulfonylurea on the other hand, might increase risk for pancreatitis (Blomgren et al. 2002) and solid tumors (Currie et al. 2009).

Third, there are several specific limitations to the use of an adverse event reporting databases, which are virtually the only clinical data available for GLP1 receptor agonists at this time. Incomplete patient characteristics (i.e. medical history, drug history, compliance, and comorbidities) and reporting bias dependent on media attention are the most important of those limitations. Long-term follow-up data, obtained in long-term prospective randomized trials, are needed to disentangle the knot. Hopefully they will emerge from studies on monitoring for cardiovascular safety that are currently ongoing (Drucker \& Goldfine 2011).

Finally, there are noticeable differences between the GLP1 receptor agonists and DPP4 inhibitors from both pharmacokinetic and dynamic standpoints. Namely the receptor agonists induce a prolonged and elevated activation of the downstream pathways. The DPP4 inhibitors on the other hand, only induce a temporary 
augmented GLP1R stimulation postprandially, when endogenous incretins, and thus not only GLP1, are secreted. In addition, DPP4 inhibition might lead to impaired immune function and increased risk for cancers through immunomodulatory of target effects (Havre et al. 2008, Matteucci \& Giampietro 2009).

\section{Conclusions}

Incretin-based therapies, both GLP1 agonists and DPP4-inhibitors, are extremely potent and effective antidiabetic agents. They have quickly made their way into the treatment paradigm of type 2 diabetes as they have an impressive safety profile and are not associated with weight increase and hypoglycemia, which often hinder the use of existing hypoglycemic agents. Nonetheless, as with any new chronic pharmacotherapy, caution is warranted. Analyses of adverse events databases suggest higher incidences of pancreatic and medullary thyroid carcinoma in patients treated with DPP4 inhibitors and GLP1 agonists. It is noteworthy that this is more likely due to stimulation of premalignant lesions, rather than induction of new neoplasms considering the relatively short duration of exposure. On the other hand, there are some promising reports of beneficial effects on colon and breast cancer, but these findings largely emanate from in vitro and animal studies and need to be confirmed in vivo.

For now the benefits of incretin-based pharmacotherapy in patients suffering from type 2 diabetes far outweigh the scarce reports on their putative carcinogenic properties.

Nonetheless, it the absence of long-term follow-up data in humans, they remain contraindicated in patients with a personal or family history of MTC or multiple endocrine neoplasia type 2.

\section{Take home messages}

1. GLP1 receptor agonists and DPP4 inhibitors are appealing therapies in patients with type 2 diabetes, as they improve glycemic control without hypoglycemia or weight gain, and even induce weight loss.

2. Safety signals regarding thyroid and pancreas neoplasms have emerged from preclinical studies in rodents, but these findings have not been confirmed in humans. As with all new pharmacotherapies, caution is warranted but up until now the data do not justify screening for those or other malignancies in patients treated with incretinbased therapies.

\section{Search methods}

Medline search 'GLP1, glucagon like peptide 1; DPP4 inhibitor, dipeptidyl peptidase-4' and combinations with 'cancer, carcinoma, malignancy, neoplasm, pancreas, thyroid, breast, colon, intestinal'. Last search performed on 10 March 2012.

\section{Declaration of interest}

C Mathieu is consultant for and KU Leuven has received review support or honoraria from NovoNordisk, MSD, Eli Lilly, Sanofi, Novartis, AstraZeneca, BMS, Janssen Pharmaceuticals, Pfizer, Medtronic, and Roche. The other authors have no conflicts of interest.

\section{Funding}

This review did not receive any specific grant from any funding agency in the public, commercial or not-for-profit sector.

\section{References}

Agerso H, Jensen LB, Elbrond B, Rolan P \& Zdravkovic M 2002 The pharmacokinetics, pharmacodynamics, safety and tolerability of NN2211, a new long-acting GLP-1 derivative, in healthy men. Diabetologia 45 195-202. (doi:10.1007/s00125-001-0719-z)

Ahren B, Simonsson E, Larsson H, Landin-Olsson M, Torgeirsson H, Jansson PA, Sandqvist M, Bavenholm P, Efendic S, Eriksson JW et al. 2002 Inhibition of dipeptidyl peptidase IV improves metabolic control over a 4-week study period in type 2 diabetes. Diabetes Care $\mathbf{2 5}$ 869-875. (doi:10.2337/diacare.25.5.869)

Arzneimittelkommission der deutschen Ärzteschaft 2011 "Aus der UAW-Datenbank": pankreaskarzinome im zusammenhang mit Exenatid (Byetta $\left.{ }^{\circledR}\right)$. Dtsch Arztebl 108 A-1080.

Baggio LL \& Drucker DJ 2004 Clinical endocrinology and metabolism. Glucagon-like peptide-1 and glucagon-like peptide-2. Best Practice \& Research. Clinical Endocrinology \& Metabolism 18 531-554. (doi:10.1016/j. beem.2004.08.001)

Ban K, Hui S, Drucker DJ \& Husain M 2009 Cardiovascular consequences of drugs used for the treatment of diabetes: potential promise of incretin-based therapies. Journal of the American Society of Hypertension 3 245-259. (doi:10.1016/j.jash.2009.04.001)

Bayliss WM \& Starling EH 1902 The mechanism of pancreatic secretion. Journal of Physiology 28 325-353.

Bjerre Knudsen L, Madsen LW, Andersen S, Almholt K, de Boer AS, Drucker DJ, Gotfredsen C, Egerod FL, Hegelund AC, Jacobsen H et al. 2010 Glucagon-like peptide-1 receptor agonists activate rodent thyroid C-cells 
causing calcitonin release and C-cell proliferation. Endocrinology 151 1473-1486. (doi:10.1210/en. 2009-1272)

Blomgren KB, Sundstrom A, Steineck G \& Wiholm BE 2002 Obesity and treatment of diabetes with glyburide may both be risk factors for acute pancreatitis. Diabetes Care 25 298-302. (doi:10.2337/diacare.25.2.298)

Brubaker PL \& Drucker DJ 2004 Minireview: glucagon-like peptides regulate cell proliferation and apoptosis in the pancreas, gut, and central nervous system. Endocrinology 145 2653-2659. (doi:10.1210/en.2004-0015)

Bullock BP, Heller RS \& Habener JF 1996 Tissue distribution of messenger ribonucleic acid encoding the rat glucagon-like peptide-1 receptor. Endocrinology 137 2968-2978. (doi:10.1210/en.137.7.2968)

Buse JB, Rosenstock J, Sesti G, Schmidt WE, Montanya E, Brett JH, Zychma M, Blonde L \& Group L-S 2009 Liraglutide once a day versus exenatide twice a day for type 2 diabetes: a 26-week randomised, parallel-group, multinational, open-label trial (LEAD-6). Lancet 374 39-47. (doi:10.1016/S0140-6736(09)60659-0)

Butler AE, Galasso R, Matveyenko A, Rizza RA, Dry S \& Butler PC 2010 Pancreatic duct replication is increased with obesity and type 2 diabetes in humans. Diabetologia 53 21-26. (doi:10.1007/s00125-009-1556-8)

Cure P, Pileggi A \& Alejandro R 2008 Exenatide and rare adverse events. New England Journal of Medicine 358 1969-1970 (discussion 1971-1972). (doi:10.1056/ NEJMc0707137)

Currie CJ, Poole CD \& Gale EA 2009 The influence of glucose-lowering therapies on cancer risk in type 2 diabetes. Diabetologia 52 1766-1777. (doi:10.1007/ s00125-009-1440-6)

Denker PS \& Dimarco PE 2006 Exenatide (exendin-4)induced pancreatitis: a case report. Diabetes Care 29471. (doi:10.2337/diacare.29.02.06.dc05-2043)

Dore DD, Bloomgren GL, Wenten M, Hoffman C, Clifford CR, Quinn SG, Braun DK, Noel RA \& Seeger JD 2011 A cohort study of acute pancreatitis in relation to exenatide use. Diabetes, Obesity \& Metabolism 13 559-566. (doi:10.1111/j.1463-1326.2011.01376.x)

Drucker DJ \& Goldfine AB 2011 Cardiovascular safety and diabetes drug development. Lancet 377 977-979. (doi:10.1016/S0140-6736(10)62299-4)

Drucker DJ, Mojsov S \& Habener JF 1986 Cell-specific posttranslational processing of preproglucagon expressed from a metallothionein-glucagon fusion gene. Journal of Biological Chemistry 261 9637-9643.

Drucker DJ, Erlich P, Asa SL \& Brubaker PL 1996 Induction of intestinal epithelial proliferation by glucagon-like peptide 2 . PNAS 93 7911-7916. (doi:10.1073/pnas.93.15.7911)

Elashoff M, Matveyenko AV, Gier B, Elashoff R \& Butler PC 2011 Pancreatitis, pancreatic, and thyroid cancer with glucagon-like peptide-1-based therapies. Gastroenterology 141 150-156. (doi:10.1053/j.gastro.2011.02.018)
Evans JM, Donnelly LA, Emslie-Smith AM, Alessi DR \& Morris AD 2005 Metformin and reduced risk of cancer in diabetic patients. BMJ 330 1304-1305. (doi:10.1136/bmj. 38415.708634.F7)

Fehmann HC \& Habener JF 1992 Insulinotropic hormone glucagon-like peptide-I(7-37) stimulation of proinsulin gene expression and proinsulin biosynthesis in insulinoma beta TC-1 cells. Endocrinology 130 159-166. (doi:10.1210/en.130.1.159)

Fineman MS, Bicsak TA, Shen LZ, Taylor K, Gaines E, Varns A, Kim D \& Baron AD 2003 Effect on glycemic control of exenatide (synthetic exendin-4) additive to existing metformin and/or sulfonylurea treatment in patients with type 2 diabetes. Diabetes Care 26 2370-2377. (doi:10.2337/diacare.26.8.2370)

Gallagher EJ \& LeRoith D 2011 Diabetes, cancer, and metformin: connections of metabolism and cell proliferation. Annals of the New York Academy of Sciences 1243 54-68. (doi:10.1111/j.1749-6632.2011. 06285.x)

Garg R, Chen W \& Pendergrass M 2010 Acute pancreatitis in type 2 diabetes treated with exenatide or sitagliptin: a retrospective observational pharmacy claims analysis. Diabetes Care 33 2349-2354. (doi:10.2337/ dc10-0482)

Ghatei MA, Goodlad RA, Taheri S, Mandir N, Brynes AE, Jordinson M \& Bloom SR 2001 Proglucagon-derived peptides in intestinal epithelial proliferation: glucagonlike peptide-2 is a major mediator of intestinal epithelial proliferation in rats. Digestive Diseases and Sciences 46 1255-1263. (doi:10.1023/A:1010615429639)

Ghiglione M, Uttenthal LO, George SK \& Bloom SR 1984 How glucagon-like is glucagon-like peptide-1? Diabetologia 27 599-600. (doi:10.1007/BF00276976)

Gier B, Butler PC, Lai CK, Kirakossian D, DeNicola MM \& Yeh MW 2012 Glucagon like peptide-1 receptor expression in the human thyroid gland. Journal of Clinical Endocrinology and Metabolism 97 121-131. (doi:10.1210/jc.2011-2407)

Giovannucci E, Harlan DM, Archer MC, Bergenstal RM, Gapstur SM, Habel LA, Pollak M, Regensteiner JG \& Yee D 2010 Diabetes and cancer: a consensus report. Diabetes Care 33 1674-1685. (doi:10.2337/dc10-0666)

Girman CJ, Kou TD, Cai B, Alexander CM, O’Neill EA, Williams-Herman DE \& Katz L 2010 Patients with type 2 diabetes mellitus have higher risk for acute pancreatitis compared with those without diabetes. Diabetes, Obesity \& Metabolism 12 766-771. (doi:10.1111/j.1463-1326. 2010.01231.x)

Gromada J, Bokvist K, Ding WG, Holst JJ, Nielsen JH \& Rorsman P 1998 Glucagon-like peptide 1 (7-36) amide stimulates exocytosis in human pancreatic beta-cells by both proximal and distal regulatory steps in stimulussecretion coupling. Diabetes 47 57-65. (doi:10.2337/ diabetes.47.1.57) 
Hartmann B, Thulesen J, Kissow H, Thulesen S, Orskov C, Ropke C, Poulsen SS \& Holst JJ 2000 Dipeptidyl peptidase IV inhibition enhances the intestinotrophic effect of glucagon-like peptide-2 in rats and mice. Endocrinology 141 4013-4020. (doi:10.1210/en.141.11.4013)

Havre PA, Abe M, Urasaki Y, Ohnuma K, Morimoto C \& Dang NH 2008 The role of CD26/dipeptidyl peptidase IV in cancer. Frontiers in Bioscience 13 1634-1645. (doi:10.2741/2787)

Hegedus L, Moses AC, Zdravkovic M, Le Thi T \& Daniels GH 2011 GLP-1 and calcitonin concentration in humans: lack of evidence of calcitonin release from sequential screening in over 5000 subjects with type 2 diabetes or nondiabetic obese subjects treated with the human GLP-1 analog, liraglutide. Journal of Clinical Endocrinology and Metabolism 96 853-860. (doi:10.1210/jc.2010-2318)

Hjollund KR, Deacon CF \& Holst JJ 2011 Dipeptidyl peptidase-4 inhibition increases portal concentrations of intact glucagon-like peptide-1 (GLP-1) to a greater extent than peripheral concentrations in anaesthetised pigs. Diabetologia 54 2206-2208. (doi:10.1007/s00125-0112168-7)

Imeryuz N, Yegen BC, Bozkurt A, Coskun T, VillanuevaPenacarrillo ML \& Ulusoy NB 1997 Glucagon-like peptide-1 inhibits gastric emptying via vagal afferentmediated central mechanisms. American Journal of Physiology 273 G920-G927.

Jura N, Archer H \& Bar-Sagi D 2005 Chronic pancreatitis, pancreatic adenocarcinoma and the black box in-between. Cell Research 15 72-77. (doi:10.1038/sj.cr.7290269)

Kang G, Joseph JW, Chepurny OG, Monaco M, Wheeler MB, Bos JL, Schwede F, Genieser HG \& Holz GG 2003 Epac-selective cAMP analog 8-pCPT-2'-O-Me-cAMP as a stimulus for $\mathrm{Ca}^{2+}$-induced $\mathrm{Ca}^{2+}$ release and exocytosis in pancreatic beta-cells. Journal of Biological Chemistry 278 8279-8285. (doi:10.1074/jbc.M211682200)

Kieffer TJ, McIntosh CH \& Pederson RA 1995 Degradation of glucose-dependent insulinotropic polypeptide and truncated glucagon-like peptide 1 in vitro and in vivo by dipeptidyl peptidase IV. Endocrinology 136 3585-3596. (doi:10.1210/en.136.8.3585)

Kodera R, Shikata K, Kataoka HU, Takatsuka T, Miyamoto S , Sasaki M, Kajitani N, Nishishita S, Sarai K, Hirota D et al. 2011 Glucagon-like peptide-1 receptor agonist ameliorates renal injury through its anti-inflammatory action without lowering blood glucose level in a rat model of type 1 diabetes. Diabetologia 54 965-978. (doi:10.1007/s00125-010-2028-x)

Koehler JA \& Drucker DJ 2006 Activation of glucagon-like peptide-1 receptor signaling does not modify the growth or apoptosis of human pancreatic cancer cells. Diabetes 55 1369-1379. (doi:10.2337/db05-1145)

Koehler JA, Harper W, Barnard M, Yusta B \& Drucker DJ 2008 Glucagon-like peptide-2 does not modify the growth or survival of murine or human intestinal tumor cells. Cancer Research 68 7897-7904. (doi:10.1158/00085472.CAN-08-0029)

Koehler JA, Kain T \& Drucker DJ 2011 Glucagon-like peptide-1 receptor activation inhibits growth and augments apoptosis in murine CT26 colon cancer cells. Endocrinology 152 3362-3372. (doi:10.1210/en.2011-1201)

Korner M, Stockli M, Waser B \& Reubi JC 2007 GLP-1 receptor expression in human tumors and human normal tissues: potential for in vivo targeting. Journal of Nuclear Medicine 48 736-743. (doi:10.2967/jnumed.106. 038679)

Kreymann B, Williams G, Ghatei MA \& Bloom SR 1987 Glucagon-like peptide-1 7-36: a physiological incretin in man. Lancet 2 1300-1304. (doi:10.1016/S01406736(87)91194-9)

Ligumsky H, Wolf I, Israeli S, Haimsohn M, Ferber S, Karasik A, Kaufman B \& Rubinek T 2012 The peptidehormone glucagon-like peptide-1 activates cAMP and inhibits growth of breast cancer cells. Breast Cancer Research and Treatment 132 449-461. (doi:10.1007/ s10549-011-1585-0)

Livolsi VA \& Feind CR 1979 Incidental medullary thyroid carcinoma in sporadic hyperparathyroidism. An expansion of the concept of C-cell hyperplasia. American Journal of Clinical Pathology 71 595-599.

MacDonald PE, Wang X, Xia F, El-kholy W, Targonsky ED, Tsushima RG \& Wheeler MB 2003 Antagonism of rat beta-cell voltage-dependent $\mathrm{K}^{+}$currents by exendin 4 requires dual activation of the $\mathrm{cAMP} /$ protein kinase $\mathrm{A}$ and phosphatidylinositol 3-kinase signaling pathways. Journal of Biological Chemistry 278 52446-52453. (doi:10.1074/jbc.M307612200)

Madsen LW, Knauf JA, Gotfredsen C, Pilling A, Sjögren I, Andersen S, Andersen L, de Boer AS, Manova K, Barlas A et al. 2012 GLP-1 receptor agonists and the thyroid: C-cell effects in mice are mediated via the GLP-1 receptor and not associated with RET activation. Endocrinology 153 1538-1547. (doi:10.1210/en. 2011-1864)

Masur K, Schwartz F, Entschladen F, Niggemann B \& Zaenker KS 2006 DPPIV inhibitors extend GLP-2 mediated tumour promoting effects on intestinal cancer cells. Regulatory Peptides 137 147-155. (doi:10.1016/j. regpep.2006.07.003)

Matteucci E \& Giampietro O 2009 Dipeptidyl peptidase-4 (CD26): knowing the function before inhibiting the enzyme. Current Medicinal Chemistry 16 2943-2951. (doi:10.2174/092986709788803114)

Matveyenko AV, Dry S, Cox HI, Moshtaghian A, Gurlo T, Galasso R, Butler AE \& Butler PC 2009 Beneficial endocrine but adverse exocrine effects of sitagliptin in the human islet amyloid polypeptide transgenic rat model of type 2 diabetes: interactions with metformin. Diabetes $\mathbf{5 8}$ 1604-1615. (doi:10.2337/db09-0058) 
Moore B 1906 On the treatment of diabetus mellitus by acid extract of duodenal mucous membrane. Biochemical Journal 1 28-38.

Munroe DG, Gupta AK, Kooshesh F, Vyas TB, Rizkalla G, Wang H, Demchyshyn L, Yang ZJ, Kamboj RK, Chen H et al. 1999 Prototypic G protein-coupled receptor for the intestinotrophic factor glucagon-like peptide 2. PNAS 96 1569-1573. (doi:10.1073/pnas.96.4.1569)

Nachnani JS, Bulchandani DG, Nookala A, Herndon B, Molteni A, Pandya P, Taylor R, Quinn T, Weide L \& Alba LM 2010 Biochemical and histological effects of exendin-4 (exenatide) on the rat pancreas. Diabetologia 53 153-159. (doi:10.1007/s00125-0091515-4)

Nauck M, Schmidt WE, Ebert R, Strietzel J, Cantor P, Hoffmann G \& Creutzfeldt W 1989 Insulinotropic properties of synthetic human gastric inhibitory polypeptide in man: interactions with glucose, phenylalanine, and cholecystokinin-8. Journal of Clinical Endocrinology and Metabolism 69 654-662. (doi:10.1210/jcem-69-3-654)

Nyborg NC, Molck AM, Madsen LW \& Bjerre Knudsen L 2012 The human GLP-1 analog liraglutide and the pancreas: evidence for the absence of structural pancreatic changes in three species. Diabetes 61 1243-1249. (doi:10.2337/db11-0936)

Parks M \& Rosebraugh C 2010 Weighing risks and benefits of liraglutide - the FDA's review of a new antidiabetic therapy. New England Journal of Medicine 362 774-777. (doi:10.1056/NEJMp1001578)

Rebours V, Boutron-Ruault MC, Schnee M, Ferec C, Le Marechal C, Hentic O, Maire F, Hammel P, Ruszniewski P \& Levy P 2009 The natural history of hereditary pancreatitis: a national series. Gut 58 97-103. (doi:10.1136/gut.2008.149179)

Roman S, Lin R \& Sosa JA 2006 Prognosis of medullary thyroid carcinoma: demographic, clinical, and pathologic predictors of survival in 1252 cases. Cancer $\mathbf{1 0 7}$ 2134-2142. (doi:10.1002/cncr.22244)

Sjolund K, Sanden G, Hakanson R \& Sundler F 1983 Endocrine cells in human intestine: an immunocytochemical study. Gastroenterology 85 1120-1130.

Stoffers DA, Kieffer TJ, Hussain MA, Drucker DJ, Bonner-Weir S, Habener JF \& Egan JM 2000 Insulinotropic glucagon-like peptide 1 agonists stimulate expression of homeodomain protein IDX-1 and increase islet size in mouse pancreas. Diabetes 49 741-748. (doi:10.2337/diabetes.49.5.741)

Thulesen J, Hartmann B, Hare KJ, Kissow H, Orskov C, Holst JJ \& Poulsen SS 2004 Glucagon-like peptide 2 (GLP-2) accelerates the growth of colonic neoplasms in mice. Gut 53 1145-1150. (doi:10.1136/gut.2003.035212)

Tran TT, Medline A \& Bruce WR 1996 Insulin promotion of colon tumors in rats. Cancer Epidemiology, Biomarkers \& Prevention 5 1013-1015.

Tripathy NR, Basha S, Jain R, Shetty S \& Ramachandran A 2008 Exenatide and acute pancreatitis. Journal of the Association of Physicians of India 56 987-988.

Vilsboll T, Krarup T, Deacon CF, Madsbad S \& Holst JJ 2001 Reduced postprandial concentrations of intact biologically active glucagon-like peptide 1 in type 2 diabetic patients. Diabetes 50 609-613. (doi:10.2337/ diabetes.50.3.609)

Waser B, Beetschen K, Pellegata NS \& Reubi JC 2011 Incretin receptors in non-neoplastic and neoplastic thyroid $\mathrm{C}$ cells in rodents and humans: relevance for incretinbased diabetes therapy. Neuroendocrinology 94 291-301. (doi:10.1159/000330447)

Xia Z, Dickens M, Raingeaud J, Davis RJ \& Greenberg ME 1995 Opposing effects of ERK and JNK-p38 MAP kinases on apoptosis. Science 270 1326-1331. (doi:10.1126/science.270.5240.1326)

Xu G, Stoffers DA, Habener JF \& Bonner-Weir S 1999 Exendin-4 stimulates both beta-cell replication and neogenesis, resulting in increased beta-cell mass and improved glucose tolerance in diabetic rats. Diabetes 48 2270-2276. (doi:10.2337/diabetes.48.12.2270)

Yachida S, Jones S, Bozic I, Antal T, Leary R, Fu B, Kamiyama M, Hruban RH, Eshleman JR, Nowak MA et al. 2010 Distant metastasis occurs late during the genetic evolution of pancreatic cancer. Nature $\mathbf{4 6 7}$ 1114-1117. (doi:10.1038/nature09515)

\author{
Received in final form 29 May 2012 \\ Accepted 11 June 2012 \\ Made available online as an Accepted Preprint \\ 12 June 2012
}

